\title{
APLIKASI SISTEM PAKAR UNTUK DIAGNOSA PENYAKIT HERNIA MENGGUNAKAN METODE FORWARD CHAINING DAN BACKWARD CHAINING
}

\author{
Rahmad Kurniawan', Nurul falah ${ }^{2}$ \\ 1,2 Sekolah Tinggi Manajemen Informatika Dan Komputer ( STMIK ) Dumai \\ Jln. Utama Karya Bukit Batrem Dumai-Riau Kode Pos 28811 \\ E-mail : rahmadkurniawan@mail.stmikdumai.ac.id ${ }^{1}$, nfalah45@ymail.com² $^{2}$
}

\begin{abstract}
ABSTRAK
Penyakit hernia merupakan penyakit yang mana gejalanya kurang dipahami oleh kebanyakan orang. Penyakit ini bisa menyerang pada semua usia, baik anak-anak hingga orang tua. Selain itu, kurangnya dokter spesialis, khususnya untuk daerah Kota Dumai, serta belum adanya suatu sistem yang digunakan untuk mendiagnosa penyakit hernia, juga menjadi penyebab kurangnya keinginan masyarakat untuk memeriksakan gejala-gejala yang telah dialami.Sistem untuk mendiagnosa penyakit hernia ini adalah suatu sistem terkomputerisasi yang dapat memberikan solusi yang maksimal. Dalam menyelesaikan sistem ini dapat digunakan dua metode, yaitu metode forward chaining dan metode backward chaining.Oleh karena itu, dirancang sebuah aplikasi sistem pakar yang digunakan sebagai solusi permasalahan tersebut. Aplikasi ini dibuat dengan menggunakan bahasa pemrograman Visual Basic 6.0, serta menggunakan database MySQL. Hasil dari uji coba aplikasi sistem pakar diagnosa penyakit hernia ini adalah mempermudah melakukan diagnosa penyakit hernia serta memberikan pencegahan serta solusi dari penyakit tersebut.
\end{abstract}

Kata Kunci : Sistem Pakar, Forward Chaining, Backward Chaining, Hernia

\section{PENDAHULUAN}

Kesehatan adalah suatu hal yang sangat berharga dan mahal bagi seluruh manusia, hal itu bisa dirasakan apabila seseorang sedang sakit. Oleh karena itu, kita harus mampu menjaga kesehatan dari berbagai jenis penyakit yang menyerang. Saat ini, banyak masyarakat yang tidak sadar akan gejala-gejala penyakit yang dialami, sehingga sering dianggap remeh dan menilai bahwa gejala-gejala yang dialami tersebut adalah gejala penyakit biasa yang tidak berakibat fatal. Karena kesibukan yang menyita waktu dan kurangnya konsultasi kepada dokter, membuat seseorang semakin tidak perduli terhadap gejalagejala yang dialami.

Salah satunya adalah penyakit hernia, yang mana penyakit ini gejalanya kurang dipahami oleh kebanyakan orang. Penyakit ini bisa menyerang pada semua usia, baik anak-anak hingga orang tua. Selain itu, kurangnya dokter spesialis, khususnya untuk daerah Kota Dumai, serta belum adanya suatu sistem yang digunakan untuk mendiagnosa penyakit hernia, juga menjadi penyebab kurangnya keinginan masyarakat untuk memeriksakan gejalagejala yang telah dialami.
Menurut McCarthy dalam Widodo Budihartono dan Derwin Suhartono (2014:h.4) Kecerdasan buatan merupakan cabang dari ilmu komputer yang berfokus pada pengembangan komputer untuk dapat memiliki kemampuan dan berperilaku seperti manusia. Mengutip dari jurnal Muhammad Dahria (2008:h.185) John McCarthy mengatakan bahwa AI adalah untuk mengetahui dan memodelkan proses-proses berpikir manusia dan mendesain mesin agar dapat menirukan perilaku manusia. Cerdas, berarti memiliki pengetahuan ditambah pengalaman, penalaran (bagaimana membuat keputusan dan mengambil tindakan).

Untuk membuat aplikasi kecerdasaan buatan ada dua bagian utama yang sangat dibutuhkan :

1. Basis Pengetahuan (Knowledge Base), bersifat fakta-fakta, teori, pemikiran dan hubungan antar satu dengan yang lainnya.

2. Motor Inferensi (Inference Engine), kemampuan menarik kesimpulan berdasarkan pengetahuan dan pengalaman.

Sistem pakar adalah aplikasi berbasis komputer yang digunakan untuk 
I N F O R M A T I K

Jurnal Informatika, Manajemen dan Komputer, Vol. 8 No. 2 , Desember 2016

eISSN : 2580-3042

pISSN : 1979-0694

menyelesaikan masalah sebagaimana yang dipikirkan oleh pakar. Pakar yang dimaksud disini adalah orang yang mempunyai keahlian khusus yang dapat menyelesaikan masalah yang tidak dapat diselesaikan oleh orang awam. Sebagai contoh, dokter adalah seorang pakar yang mampu mendiagnosis penyakit yang diderita pasien serta dapat memberikan penatalaksanaan terhadap penyakit tersebut. Tidak semua orang dapat mengambil keputusan mengenai diagnosis dan memberikan penatalaksanaan suatu penyakit (Kusrini, 2008:h.3).

Sebuah sistem pakar memiliki dua komponen utama yaitu basis pengetahuan dan mesin inferensi. Basis pengetahuan merupakan tempat penyimpanan pengetahuan dalam memori komputer, dimana pengetahuan ini diambil dari pengetahuan pakar. Mesin inferensi merupakan otak dari aplikasi sistem pakar. Bagian inilah yang menuntun user untuk memasukkan fakta sehingga diperoleh suatu kesimpulan. Apa yang dilakukan oleh mesin inferensi ini didasarkan pada pengetahuan yang ada dalam basis pengetahuan (Kusrini, 2008:h.3).

Menurut Wilson (1998) dalam Kusrini (2008: h.8), Runut maju berarti menggunakan himpunan aturan kondisi-aksi. Dalam metode ini, data digunakan untuk menentukan aturan mana yang akan dijalankan, kemudian aturan tersebut dijalankan. Mungkin proses menambahkan data ke memori kerja. Proses diulang sampai ditemukan suatu hasil. Proses ini disebut juga dengan deductive.

Menurut Giarattano dan Riley (1994) Kusrini (2008: h.8), Metode inferensi runut maju cocok digunakan untuk menangani masalah pengendalian (controlling) dan peramalan (prognosis).

Aturan 1:

Jika Premis 1

Dan Premis 2

Dan Premis 3

Maka Konklusi 1

Aturan 2:

Jika Premis 1

Dan Premis 3

Dan Premis 4

Maka Konklusi 2

Aturan 3 :

Jika Premis 2

Dan Premis 3

Dan Premis 5

Maka Konklusi 3

Aturan 4:

Jika Premis 1

Dan Premis 4

Dan Premis 5

Runut Balik merupakan metode penalaran kebalikan dari runut maju. Menurut Giarattano dan Riley (1994), Dalam runut balik penalaran dimulai dengan tujuan kemudian merunut balik kejalur yang akan mengarahkan ketujuan tersebut. Runut balik juga disebut sebagai goal-driven reasoning, merupakan cara yang efisien untuk memecahkan masalah yang dimodelkan sebagai masalah pemilihan terstruktur.

Menurut Schnupp (1989) dalam Kusrini (2008), Tujuan inferensi adalah mengambil pilihan terbaik dari banyak kemungkinan. Metode inferensi runut balik ini cocok digunakan untuk memecahkan masalah diagnosis.

Penelusuran didasarkan pada suatu keyakinan bahwa ada kemungkinan konklusi dari daftar konklusi merupakan salah satu tujuan atau konklusi terpilih berdasarkan fakta yang diberikan oleh user.

Misal urutannya adalah sesuai dengan urutan konklusi. Awalnya sistem akan mengambil hipotesis bahwa konklusinya adalah konklusi 1 . Untuk membuktikan hipotesisnya, sistem akan mencari premis-premis aturan yang mengandung konklusi 1. Setelah itu sistem akan meminta umpan balik kepada user mengenai premis-premis yang ditemukan tersebut. Untuk konklusi 1 premisnya adalah premis 1 , premis 2 dan premis 3 , maka sistem akan mencari tahu apakah user memilih premis-premis tersebut.

Penyakit hernia adalah penyakit yang disebabkan oleh turunnya usus ke bawah selaput perut sampai ke kantung buah zakar. Penyakit ini sering terjadi 
pada pekerja berat yang banyak mengangkut benda atau barang seperti kuli pelabuhan dan pekerja pabrik. Penyakit Hernia juga bisa menimpa orang yang sering mengejan terlalu kuat, misalnya peniup saxophone atau balon udara. Selain pengertian diatas, hernia (herniae) bisa juga diartikan sebagai menonjolnya organ dalam tubuh, keluar dari posisi aslinya, dan masuk ke posisi yang tidak normal melalui suatu defek atau lokasi yang lemah pada dinding rongga tertentu. Berdasarkan penyebab terjadinya, hernia dapat di bedakan menjadi hernia bawaan (congenital) dan hernia dapatan (akuisita).

Sedangkan menurut letaknya, hernia dibedakan menjadi hernia femoralis, umbilicalis, inguinalis, hiatus, nucleus pulposus, scrotalis. Bagian hernia terdiri dari cincin, kantong, dan isi hernia itu sendiri. Isi hernia yaitu usus, ovarium, dan jaringan penyangga usus (omentum). Bila ada bagian yang lemah dari lapisan otot dinding perut, maka usus dapat keluar ketempat yang tidak seharusnya.

perut, maka usus dapat keluar ketempat yang tidak Hernia dapat terjadi pada semua umur, baik tua maupun muda. Pada anak-anak atau bayi, lebih sering disebabkan oleh kurang sempurnanya procesus vaginalis untuk menutup seiring dengan turunnya testis atau buah zakar. Biasanya yang sering terkena hernia adalah bayi atau anak lakilaki. Pada orang dewasa, hernia terjadi karena adanya tekanan yang tinggi dalam rongga perut dan kelemahan pada otot dinding perut karena faktor usia. Tekanan dalam perut yang meningkat dapat disebabkan oleh batuk yang kronik, susah buang air besar, adanya pembesaran prostat pada pria, serta yang sering mengangkut barang-barang berat. Penyakit hernia akan meningkat sesuai dengan penambahan umur. Hal tersebut dapat disebabakan oleh melemahnya jaringan penyangga usus atau karena adanya penyakit yang menyebabkan tekanan di dalam perut meningkat.

\section{METODOLOGI PENELITIAN}

Kerangka penelitian yang di gunakan dalam penelitian ini adalah sebagai berikut :
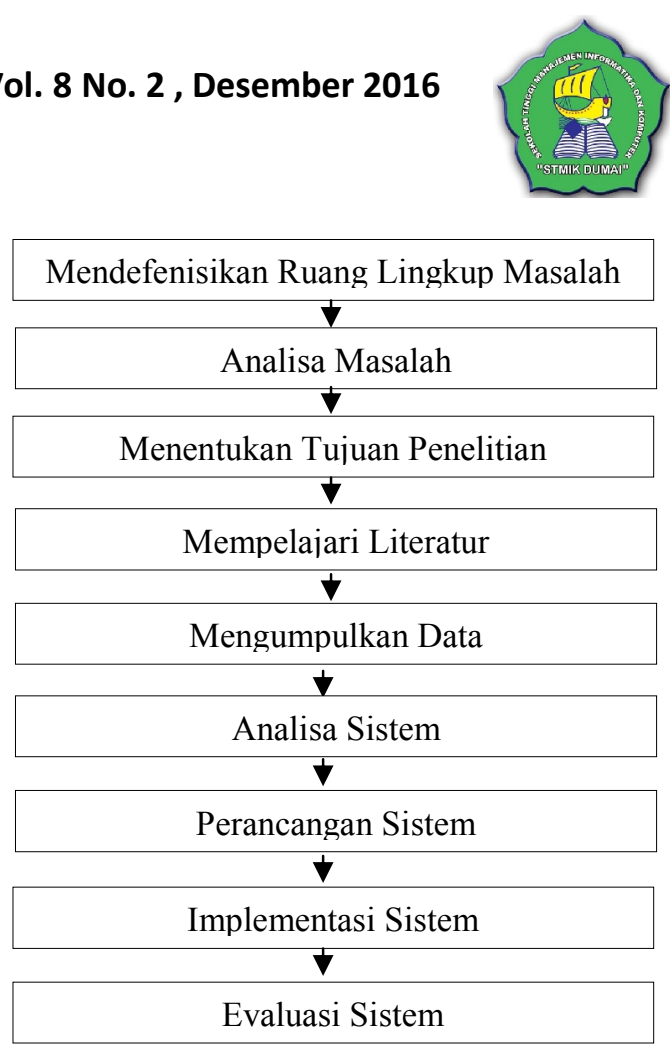

Gambar 1. Kerangka Penelitian

\section{HASIL DAN PEMBAHASAN \\ a. Context Diagram}

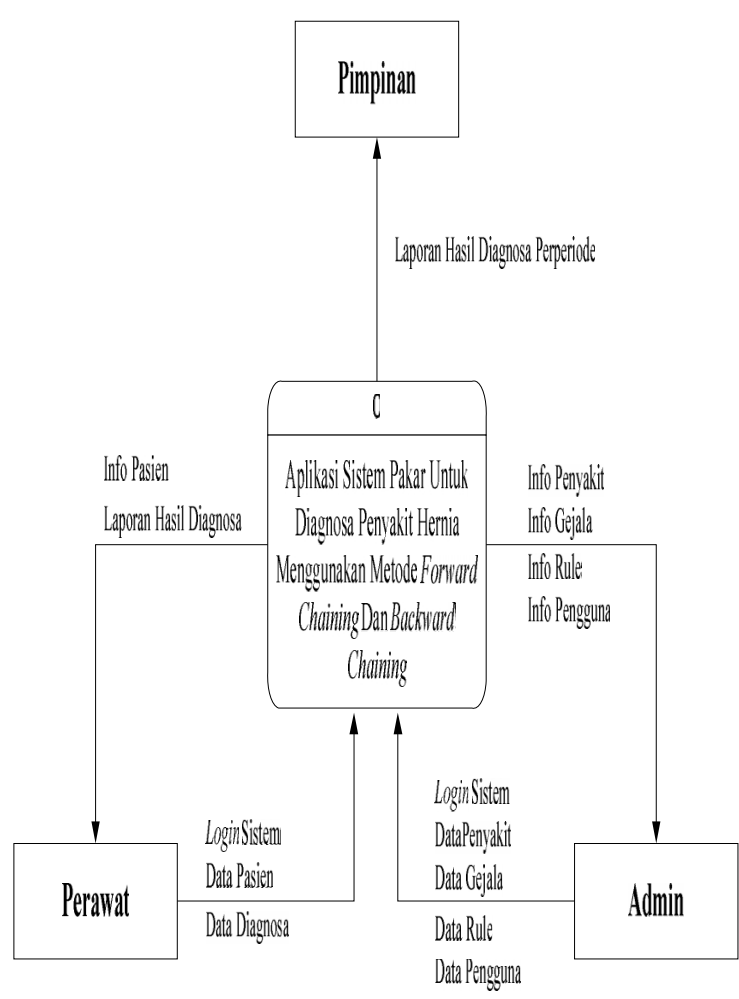

Gambar 2. Context Diagram 
I N F ORM A I K A

Jurnal Informatika, Manajemen dan Komputer, Vol. 8 No. 2 , Desember 2016

eISSN : 2580-3042

pISSN : 1979-0694

\section{b. Data Flow Diagram}

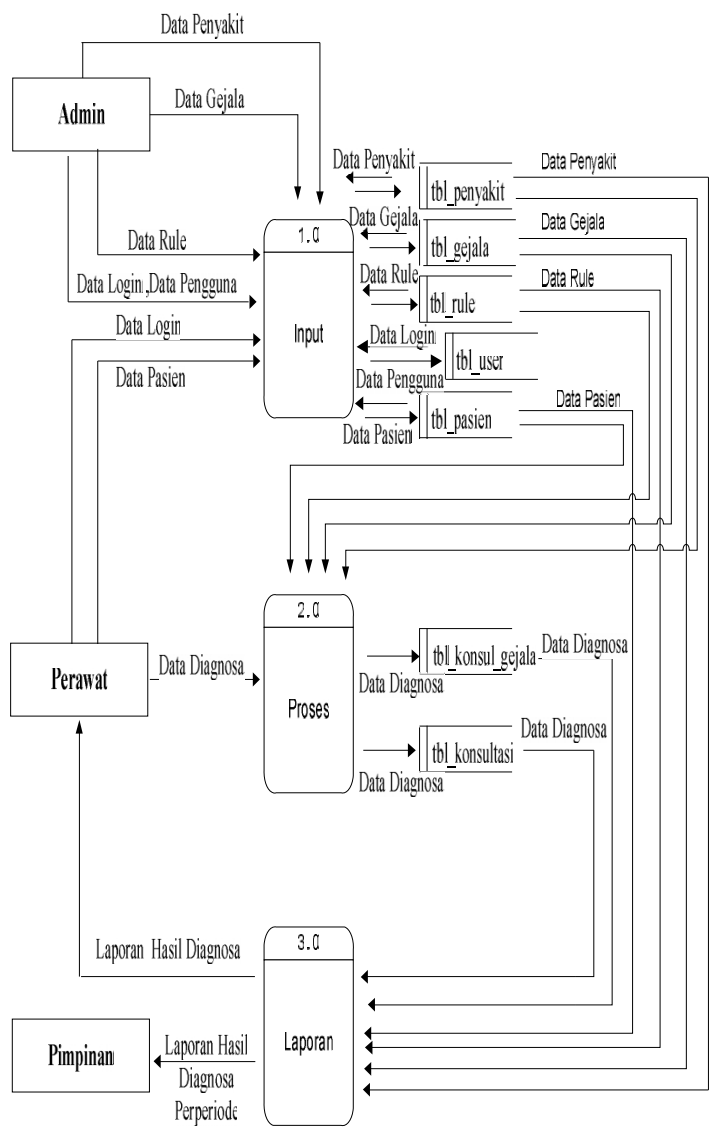

Gambar 3. Data Flow Diagram

\section{c. Aturan-aturan (Rules)}

\section{Aturan-aturan (Rules) Forward Chaining}

\section{Rule 1 :}

IF Sebuah benjolan pada bagian tubuh tertentu yang mana akan timbul bila mengejan, batuk, berdiri, berjalan, menangis dan menghilang bila tidur

AND Nyeri pada benjolan

AND Suhu badan normal

AND Denyut nadi meninggi

AND Ada sebuah benjolan dipaha

THEN Hernia Femoralis

Rule 2 :

IF Sebuah benjolan pada bagian tubuh tertentu yang mana akan timbul bila mengejan, batuk, berdiri, berjalan, menangis dan menghilang bila tidur

AND Nyeri pada benjolan

AND Ada sebuah benjolan pada atau sekitar pusar
AND Terjadi muntah tersedak yang terjadi pada anak-anak

THEN Hernia Umbilicalis

\section{Rule 3 :}

IF Sebuah benjolan pada bagian tubuh tertentu yang mana akan timbul bila mengejan, batuk, berdiri, berjalan, menangis dan menghilang bila tidur

AND Nyeri pada benjolan

AND Ada sebuah benjolan diselengkangan

AND Nyeri disertai mual dan muntah

THEN Hernia Inguinalis

Rule 4 :

IF Nyeri hulu hati

AND Rasa sakit didada

AND Muntah tersedak atau mendadak

AND Sesak nafas

AND Terjadi diatas umur 50 tahun keatas

THEN Hernia Hiatus

Rule 5 :

IF Nyeri mulai dari pantat, menjalar kebagian belakang lutut, kemudian ketungkai bawah.

AND Jika dari posisi berbaring keduduk, nyeri bertambah hebat, sedangkan bila berbaring, nyeri berkurang atau hilang.

AND Sulit berdiri atau berjalan

AND Kesemutan atau perasaan terbakar atau seperti terkena aliran listrik

THEN Hernia Nucleus Pulposus

Rule 6 :

IF Nyeri pada buah zakar (skrotum)

AND Sebuah benjolan pada buah zakar (skrotum)

AND Demam

THEN Hernia Scrotalis

\section{Aturan-aturan (Rules) Backward Chaining}

\section{Rule 7 :}

IF Hernia Femoralis

THEN sebuah benjolan pada bagian tubuh tertentu yang mana akan timbul bila mengejan, batuk, berdiri, berjalan, menangis dan menghilang bila penderita tidur

AND nyeri pada benjolan

AND ada sebuah benjolan dipaha

AND denyut nadi meninggi

AND suhu badan normal.

\section{Rule 8 :}

IF Hernia Umbilicalis

THEN sebuah benjolan pada bagian tubuh tertentu yang mana akan timbul bila mengejan, batuk, 
I N F O R M A T I K A

Jurnal Informatika, Manajemen dan Komputer, Vol. 8 No. 2 , Desember 2016

eISSN : 2580-3042

pISSN : 1979-0694

berdiri, berjalan, menangis dan menghilang bila penderita tidur

AND nyeri pada benjolan

AND ada sebuah benjolan pada atau sekitar pusar

AND terjadi muntah tersedak yang terjadi pada anak-anak.

\section{Rule 9 :}

IF Hernia Inguinalis

THEN sebuah benjolan pada bagian tubuh tertentu yang mana akan timbul bila mengejan, batuk, berdiri, berjalan, menangis dan menghilang bila penderita tidur

AND nyeri pada benjolan

AND ada sebuah benjolan diselengkangan

AND nyeri disertai mual dan muntah.

Rule 10 :

IF Hernia Hiatus

THEN nyeri hulu hati

AND rasa sakit didada

AND muntah tersedak atau mendadak

AND sesak nafas

AND terjadi diatas umur 50 tahun keatas.

\section{Rule 11:}

IF Hernia Nucleus Pulposus

THEN nyeri mulai dari pantat, menjalar kebagian belakang lutut, kemudian ketungkai bawah

AND jika dari posisi berbaring keduduk, nyeri bertambah hebat, sedangkan bila berbaring, nyeri berkurang atau hilang

AND sulit berdiri atau berjalan

AND kesemutan atau perasaan terbakar atau seperti terkena aliran listrik

\section{Rule 12 :}

IF Hernia Scrotalis

THEN nyeri pada buah zakar (skrotum)

AND sebuah benjolan pada buah zakar (skrotum)

AND demam.

\section{d. Pohon Keputusan Pakar}

Pohon Keputusan dengan Forward Chaining 
I N F O R M A I K A

Jurnal Informatika, Manajemen dan Komputer, Vol. 8 No. 2 , Desember 2016

eISSN : 2580-3042

pISSN : 1979-0694

\section{e. Tampilan Interface}

1. Menu Utama

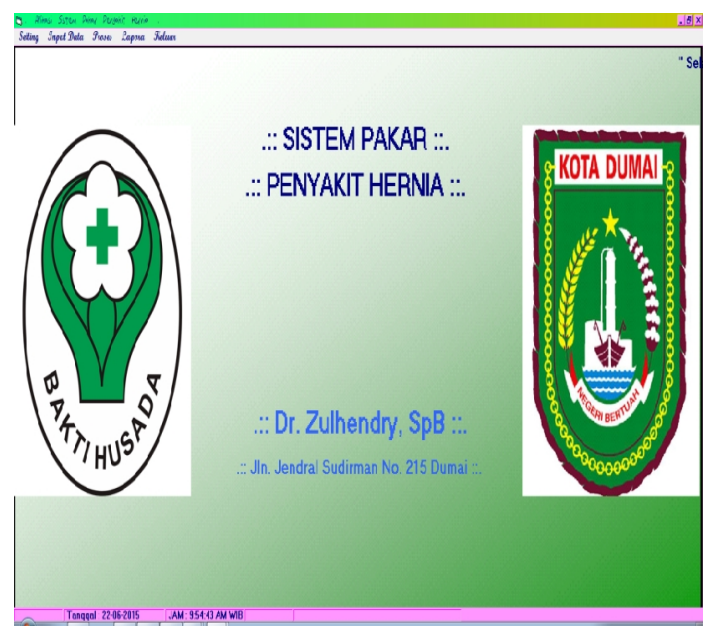

Gambar 7. Form Menu Utama

Pada form menu utama ini, sistem menyediakan menu setting yang terdiri dari sub menu User dan Ganti Password, menu input data yang terdiri dari sub menu input data penyakit, input data gejala, input data rule, input data pasien, menu proses yang terdiri dari sub menu diagnosa, menu laporan yang terdiri dari sub menu laporan hasil diagnosa,laporan diagnosa perperiode dan menu keluar.

\section{Form Diagnosa}

a. Form Diagnosa Forward Chaining

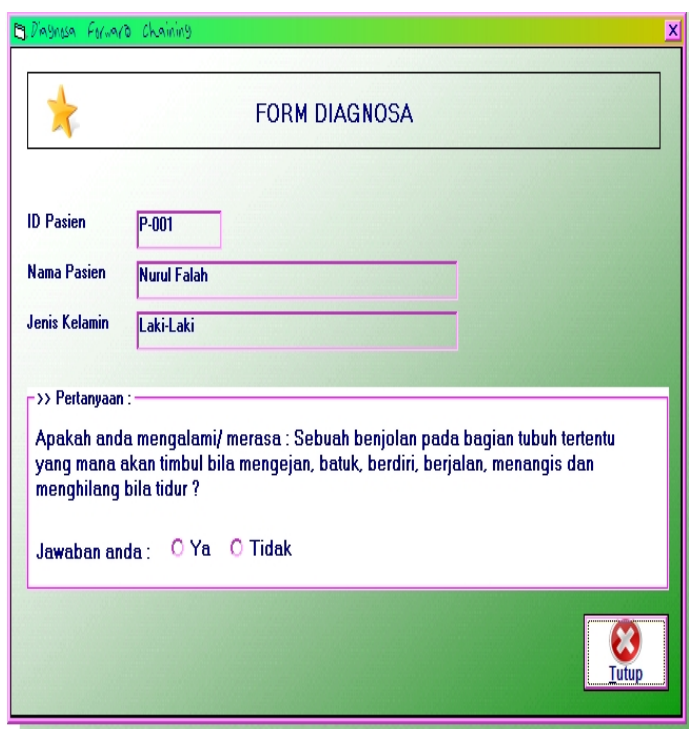

Gambar 8. Form Diagnosa Forward Chaining

Form Diagnosa Forward Chaining ini merupakan form proses diagnosa penyakit hernia menggunakan metode forward chaining, pada form

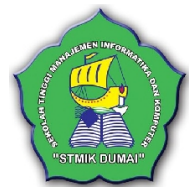

ini pasien diminta untuk menjawab setiap pertanyaan gejala yang di tampilkan oleh sistem.

b. Form Diagnosa Backward Chaining

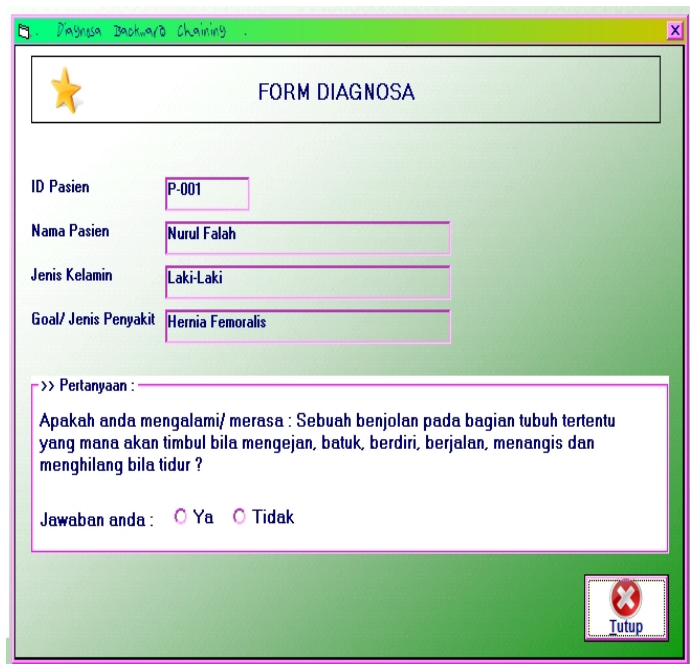

Gambar 9. Form Diagnosa Forward Chaining

Form Diagnosa Backward Chaining ini merupakan form proses diagnosa penyakit hernia menggunakan metode backward chaining, pada form ini pasien diminta untuk menjawab setiap pertanyaan gejala yang di tampilkan oleh sistem, perbedaan antara form diagnosa menggunakan metode forward chaining dan metode backward chaining adalah pada form diagnosa menggunakan metode backward chaining, gejala yang ditampilkan oleh sistem merupakan batasan gejala dari suatu penyakit, dimana penyakitnya telah dipilih pada form tanya diagnosa.

\section{Laporan Hasil Diagnosa}

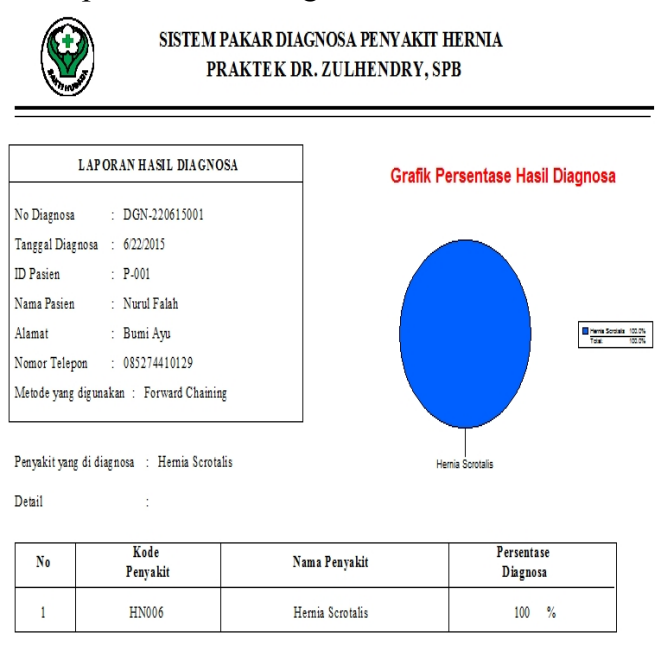

Gambar 10. Laporan Hasil Diagnosa 
I N F ORM A T I K A

Jurnal Informatika, Manajemen dan Komputer, Vol. 8 No. 2 , Desember 2016

eISSN : 2580-3042

pISSN : 1979-0694

\section{KESIMPULAN}

Berdasarkan hasil dari pengujian dan analisa program yang telah dilakukan, maka dapat diperolah kesimpulan sebagai berikut :

1. Aplikasi ini dapat membantu pekerjaan dokter/ perawat dalam melakukan diagnosa terhadap pasien.

2. Dengan menggunakan aplikasi ini, pasien dapat mengetahui hasil diagnosa penyakitnya serta solusi dan pencegahan dari penyakit tersebut tanpa harus bertemu dokter.

3. Aplikasi ini dibuat dinamis, sehingganya jika suatu saat nanti ada perubahan pengetahuan mengenai proses diagnosa maupun penambahan, penghapusan gejala-gejala penyakit hernia, dapat diubah langsung diaplikasi.

\section{REFERENSI}

Adi Nugroho. (2011). Perancangan Dan Implementasi Sistem Basis Data. Andi. Yogyakarta.

Deddy Kusbianto. (2010). Analisis Dan Perancangan Sistem Informasi. STMIK Yadika. Pasuruan.

Edhy Sutanta. (2011). Basis Data Dalam Tinjauan Konseptual. Cv. Andi Offset. Yogyakarta.

Hanif Alfatta. (2007). Analisis Dan Perancangan Sistem Informasi. Cv. Andi Offset. Yogyakarta.

Haviluddin. 3 September 2009. Memahami penggunaan diagram arus data. Jurnal Informatika Mulawarman. Volume 4. Hal 4.

Indrajani. (2011). Perancangan Basis Data Dalam All in 1. PT. Elex Media Komputindo. Jakarta.

- (2011). Bedah Kilat 1 Jam Pengantar dan Sistem Basis Data. PT. Elex Media Komputindo. Jakarta.

Kusrini. (2008). Aplikasi Sistem Pakar. Cv. Andi Offset. Yogyakarta.

M. Agus J. Alam. (2010). Cara Mudah Menggunakan Crystal Report XI. PT. Elex Media Komputindo. Jakarta

Muhammad Dahria. 2 agustus 2008. Keceradasan buatan (artificial intelligence). Jurnal SAINTIKOM, Volume 5. Hal 185.

Prasetia, Catur Edi Widodo. (2013). Tips Coding Interfacing Port USB \& Port Serial Menggunakan VB. Cv. Andi Offset. Yogyakarta.

Uus Rusmawan. (2011). Visual Basic 6.0 Untuk Semua Tingkatan. PT. Elex Media Komputindo. Jakarta.

Wahana Komputer. (2010). Panduan Belajar Mysql Database Server. Mediakita. Jakarta.

Widodo Budiharto, Derwin Suhartono (2014). Artificial Intelligence Konsep dan Penerapannya. Cv. Andi Offset. Yogyakarta. 